\title{
8 The quest for independent living in Finland
}

\author{
Youth shelter as a critical moment in \\ young adults' life courses
}

Miia Lähde and Jenni Mölkänen

\section{Introduction}

In Finland, as in most countries of the Global North, turning 18 signposts juridical adulthood which is accompanied by changes in citizen rights and responsibilities. It also marks a new kind of adult status, one associated with cultural expectations regarding education, commitment to work life, intimate relationships, and independent living. ${ }^{1}$ During the first decades of the 21 st century, youth policy efforts aimed to prevent social exclusion and promote the participation of young people have contributed to the measures developed from a societal perspective emphasizing rapid transitions and activation, which some young people perceive as oppressive control and therefore unsuited to their actual situations (e.g. Brunila and Lundahl 2020; Mertanen 2020), Alongside these emphases, the perspectives and needs of young people as they forge their independent lives in the phase of 'emerging adulthood' (Arnett 2000; Juvonen 2015, p. 194), and the particularities of this life stage as framed by current political-economic structures and societal transformations (e.g. Miles 2000, pp. 35-48; Aapola and Ketokivi 2005; MacDonald and Shildrick 2018), have remained largely unrecognized in public debate and services.

This chapter addresses the challenges young people face in pursuing independent living, and their views on using the support offered to achieve this independence. It focuses on young people in Finland who have experienced difficulties in their transition to adulthood. We analyze the significance of a third sector service provider, the Finnish Red Cross Youth Shelters, in supporting young people in their quest to achieving an independent adult life. In theoretical terms, the chapter provides a discussion on 'critical moments' (discussed later) by analyzing how affiliation to a particular service or form of support can be critical to young people's wellbeing and further their possibilities of independent living. In practical terms, it contemplates the necessity of services sensitive to the diverse needs prevalent during the emerging adulthood phase.

The conceptualizations, timing and institutional support of youth independence vary historically and culturally. Finnish youth move away from their childhood homes at an earlier age than youth in most other European

DOI: $10.4324 / 9781003110019-12$ 
countries (Eurostat 2019). Becoming independent, also viewed in Finnish society as a culturally defined ideal, is one of the main reasons for moving out from one's childhood home (Myllyniemi 2017, p. 22; Myllyniemi and Suurpää 2009). Nordic societies and their rearing cultures value early independence, which is reflected in the support provided by the state to enable young people to live separately from their parents after a certain age. ${ }^{2}$ The Finnish state supports the process of young people's independence by providing welfare services, including economic subsidies such as study allowances, housing support and unemployment insurance (Myllyniemi and Kiilakoski 2018, pp. 16-17).

Youth services in Finland are based on the Nordic welfare model, emphasizing wide and equal access to the services. They include, for instance, educational, social work, employment, primary and specialized health care services as well as multi-professional counselling and support services (Gissler et al. 2018). Third sector, consisting of non-governmental and non-profit organizations that work alongside the public and private sectors, complements the system of welfare service production (Hiilamo and Saari 2010; Pirkkalainen et al. 2018). It has been argued that despite the state support and a relatively well-covered service system, young people who leave their childhood home early are especially prone to facing economic risks (Berngruber 2016, pp. 194-195; Myllyniemi 2017, pp. 22-23, p. 60). Moreover, inflexible and bureaucratic services, growing dependency on the system and the lack of genuine social encounters have driven exclusion instead of improving youths' inclusion into the welfare regime (Närhi et al. 2013).

Our study is based on a research collaboration between the ALL-YOUTH Research Project and a third sector service provider, the Finnish Red Cross Youth Shelters $^{3}$ (Honkatukia et al. 2020). The Youth Shelters operate in the Helsinki metropolitan area (namely the cities of Helsinki, Espoo and Vantaa) and two other big cities in southern Finland (Tampere and Turku). They augment the municipal youth services, which are versatile but also in high demand in these areas compared to many other parts of the country. The shelters are intended to support young people (up to 25 years of age) during times of crisis, such as when they face problems related to family, other social relationships, school and housing, or have unresolved issues about independent living. This aid is designed to be temporary and encompasses a broad range of voluntary and free of charge services, including short-term accommodation, personal and family meetings (Punainen Risti 2017). ${ }^{4}$ One of these services under the Kotipolku Project helps young adults aged between 18 and 24 years in the capital metropolitan area to find a home and support their independent living (Kotipolku 2020). ${ }^{5}$ Henceforth, we refer to these services by the abbreviation 'YS' (Youth Shelters).

In this chapter, we examine, based on qualitative life course interviews, young people's reasons for seeking support from the YS as well as the kinds of support they found helpful. Our analysis is inspired by a biographical perspective and the concept of a 'critical moment' as a way to compare narratives of transition and capture the importance of life events in trajectories of 
young people (Thomson et al. 2002, 2004; Thomson 2007; Thomson and Holland 2015) (see the section titled 'Conceptual framework'). By focusing on young persons' affiliation to YS as a 'critical moment' we want to: (1) draw attention to the formation of young people's support needs and the significance of their service experiences in biographical context; and (2) consider how these experiences can inform respective practice with young people. Rather than viewing young people only as vulnerable and marginalized (Brunila et al. 2019, p. 113), such an approach helps one understand them as agents who actively negotiate and manage their lives and identities, and in so doing, participate in and contribute to society in a variety of ways (Honkatukia et al. 2020, pp. 25-28; Thomson et al. 2004, p. 221).

First, we lay out the conceptual framework based on a biographical perspective of the life course transitions of these youth. Then, we present our data and methods, focusing on young people's affiliations to the third sector service YS. Using these 'critical moments' in these young adults' life stories, we explore experiences and events that have produced twists and turns in their transitions and heightened their need for support, and we address how these services can provide the needed assistance. To begin with, we discuss three common underlying themes that manifested in the young adults' narratives, namely insecurities in close relationships, illness or struggle with psycho-social wellbeing and moving residence, which influenced their contact with the YS, and second, we consider the young people's need for support and their experiences of receiving it. We conclude by discussing our results and their possible implications to future studies and the development of services promoting youth independence and wellbeing in Finland.

\section{Conceptual framework}

The independency of Finnish youth is typically perceived as increasing emotional, social and economic independence from parents or the familial context of growing up in the transition to independent living. The normative expectation of adultness is primarily marked by autonomy from one's childhood family (Hoikkala 1993, pp. 82-85). This process, which lies at the heart of the youth period (Arnett 2001, p. 134; Miles 2000), is guided by a standardized path, and deviations from it are easily considered as a matter of concern (Furlong 2013). In this chapter, we approach the process(es) of independence as a series of personally negotiated stages and movements over time (Jones 2009, pp. 140-141; Montgomery 2007, p. 283), taking place through interrelated institutionalized transitions associated with the cultural ideals of adulthood and the expected timings of the life course.

There is a consensus that transitions to adulthood have typically become longer and more complex (Furlong and Cartmel 2007), and youths' biographies are increasingly affected by both institutional structuring and freedom of choice. It is, therefore, recognized that the shapes and timings of transition processes vary considerably by social and materially based inequalities (Thomson and Holland 2015, p. 724). For example, young adults leaving care 
are somewhat 'forced' to transition to independent living quickly or at once, with no option to return (Kulmala and Fomina, this volume). The ongoing transformations in the global economy and labour market also mean that the notion of achieving adulthood, which is the objective of the transitions, has become ambiguous (e.g. Blatterer 2007; Thomson and Holland 2015; Woodman and Wyn 2015; Cameron et al. 2018). It is argued that the associated instability and insecurity are likely to be the most sharply felt by young disadvantaged people (MacDonald and Shildrick 2013, 2018).

Traditionally, a stable position in working life is highly valued in Finland (Brunila et al. 2013; Aapola-Kari and Wrede-Jäntti 2017), and education is considered a requirement for entering the working life (Aaltonen et al. 2018, p. 5). While research and policy interests have mainly focused on transitions in the context of education and work, research on youth in the 21st century has increasingly touched upon how these transitions intersect with other domains in young people's lives over time, creating the overall form and character of their transitions to adulthood (MacDonald and Shildrick 2018). Developing the ideas laid down in theories of late modernity (e.g. Beck 1992; Giddens 1991), such studies have aimed to document and understand how young people may be experiencing and negotiating themselves and their lives in new social conditions (cf. Du Bois-Reymond 1998).

Our approach to processes of independence is inspired by the biographical perspective and the idea of 'critical moments' developed by the researchers in the longitudinal 'Inventing Adulthoods' study (Henderson et al. 2007). Instead of devising a narrow individual focus or concentrating on policyrelated categories, it provides a way to appreciate young people's lives holistically and of seeing also "the limited character of their 'choices' and the critical role of timing in their biographies" (Thomson et al. 2004, p. 237). It emphasizes young people's subjective understandings, feelings and competencies. Adapting this perspective, we join the critique of the normative model, expecting sovereign individuals who are able, in every situation, to evaluate, choose and act (Juvonen 2015, p. 164), and we place at the centre of inquiry individuals who have different, socially and materially based resources and skills with which they orient towards the future (Skeggs 2014, p. 11, pp. 57-59).

According to Thomson (2007, pp. 103-104), the biographical approach encourages one to pay attention to interrelated domains of an individual's life as well as young people's agency and responses to their life events and circumstances. The perspective draws upon the life course theory which identifies four central factors that together have explanatory value in determining unfolding life chances: historical time and place, the timing of lives, linked or interdependent lives and human agency (Elder Jr. 1994; Thomson and Holland 2015, p. 724). It recognizes, as Woodman and Leccardi (2015, p. 711) note, that engagement in one area of life, demands 'an investment of time and energy that is likely to put pressure on the time and energy that is available to invest in other biographical fields at play in a young person's particular social location'. A 'critical moment' can be understood as events or 
experiences in a person's life which are consequential to their biography; that is, they are defined by their roles in providing biographical momentum and structure (Thomson et al. 2002). ${ }^{6}$ The power of the critical moments can be felt at the time, but their significance is often recognized only in retrospect in the narration of the life course (MacDonald and Shildrick 2013, p. 155).

As part of the ALL-YOUTH Project, our study focuses on young adults' constructions of their pasts in one-off interviews and the manner in which these constructions intertwined with their sense of their current lives and related future prospects (Kulmala and Fomina, this volume; Wilson et al. 2007). We take a critical realist stand to the relationship between the "life as lived' and 'life as told' (Thomson 2007, p. 77), as we are interested in the social circumstances related to life events and young people's experiences of them, even while accepting that knowledge (young people's accounts of themselves as well as our interpretations) is defined by the interactional setting in which they are produced (e.g. the interview schedule and interview style) and, as such, a discursively bound and changing social construction (Lewis-Beck et al. 2004).

Our use of the notion of 'critical moment' is twofold. On the one hand, we utilize it as a tool in data gathering, asking the interviewees to identify events or experiences they themselves found particularly meaningful for their respective life course. On the other hand, our analysis focuses on the affiliation of this research's participants to the YS as 'critical moments', to consider their biographical salience to these young people's transitions to independent living.

\section{Data and methods}

We draw upon 17 thematic life course interviews with 18-to-24-year-old young adults in two major urban areas in Finland. The participants were recruited through the YS in collaboration with its staff. They shared one aspect; they all had faced challenges in transition to independence and sought help from the YS. Otherwise, they were a heterogeneous group in terms of life situations, gender ( 12 females, 3 males and 2 transgenders), ${ }^{7}$ ethnicity, family background and social class (ranging from seemingly middle class to socioeconomically disadvantaged). Many talked about difficult family circumstances, and some had been in foster care. Some had moved to Finland as children or young persons, and two had a refugee background (Honkatukia et al. 2020). ${ }^{8}$ Some had grown up in their current place of residence; however, as is typical for youth transitions in Finland, many had moved towards the urban centres of southern Finland after leaving their childhood homes. Four researchers, including the authors of this chapter, conducted the interviews between March and June 2019. All the interviews were conducted in a place chosen by the interviewee, most often at the YS and sometimes in a café. Pseudonyms are used for the young people, and none of the places, with the exception of the capital (Helsinki) metropolitan area, are named throughout the reporting. ${ }^{9}$ 
The collaboration with the YS allowed us to interview 'difficult-to-reach' young adults who often decline to participate in such studies. Those who voluntarily participated in the study spoke vividly about their experiences, providing qualitative material rich in descriptions of their social relationships, their educational, work and housing paths and institutional encounters. While the data are not representative of either the youth population in Finland or those who seek assistance from the YS, ${ }^{10}$ they provide a multifaceted view of the obstacles to independent living faced by young people in Finnish society and their experiences as users of welfare services. It is also possible that the recruitment process may have led to a positive bias in our data, emphasizing young persons who are predominantly satisfied with YS or confident enough to verbally communicate their life stories.

To encourage the young people to share their stories and reflections of their life courses, we combined a voluntary task-based activity, called the 'lifeline', and thematic life story interviews. As our approach was strongly informed by research ethics and sensitivity to the issues arising in the context of the YS, ${ }^{11}$ we assumed that a visual tool could help to facilitate the discussion and allow the interviewees to signal what kinds of things they were ready to expose and talk about with the interviewers (cf. Wilson et al. 2007). We asked each interviewee to draw a lifeline (or 'any visual representation') and jot down on a sheet of paper events or experiences (both positive and negative) that they found particularly meaningful in their life histories. These lifelines provided some structure to the interview conversations, as we invited the participants to elaborate upon their notes of particular moments and then adapted our interview themes to their accounts. The interview schedule included themes of social relationships (family and friends), school, work (other institutional encounters), leisure time, future orientation and Finnish society. We aimed to keep the interviews flexible, allowing the interviewee to control the pace and direction of the conversation. One major advantage of the lifeline was that our interviewees used it to raise sensitive issues (such as illness, substance abuse and their relationships as clients of the social and health services) without us having to ask about them (ibid.).

In the ALL-YOUTH Study, we wanted to take account of young people's feelings in the formation of citizenship experiences and paid attention to the meanings young people gave to their situations and experiences, and to the relationships between different fields of life. We analyzed the interview transcripts by referring to central research themes ${ }^{12}$ and timing of life events in terms of 'critical moments' (Honkatukia et al. 2020, p. 11, pp. 21-23) ${ }^{13}$. Our analytic focus in this chapter rests on the interviewees' affiliations with the YS and their consequences on their biographies. Using this information, we identified thematic parallels between these young adults' life situations and need for support, and we considered the role of voluntary non-governmental services in supporting their wellbeing during their transitions to adulthood.

While only 4 interviewees out of 17 marked the YS on their lifelines (Anni, 22 years; Pinja, 20 years; Linnea, 20 years and Nikki, 19 years), most of the interviewees emphasized its positive impacts on their respective situations in 
their accounts. We observed a slight gender difference in the discourse, in that males placed less emphasis on the importance of mental support and the overall significance of the YS in their lives. All the interviewees were nevertheless willing to discuss the services and support they received, which justifies including all the interviews in this analysis.

\section{Accounts of entering YS}

The reasons and avenues for becoming involved with the YS were varied, such as needing support to maintain a daily rhythm (to go to school, for instance), solving the practical issues associated with navigating the service system, managing to live alone, having a safe space to sleep or discussing one's life situation. The interviewees' contact with the Kotipolku Project in the capital metropolitan area was typically related to resolving housing issues, such as finding one's own home or waiting to move into it and requesting support for independent living in one's own home. Some interviewees had found the service by themselves, while others came upon it with assistance from their family members or a professional in another service (social worker, counselling psychologist or youth worker, for instance).

Looking at the interviewees' lives 'backwards' (starting with their presence at the shelter) revealed three key biographical themes that commonly intersected these young people's life stories, informing us about their previous struggles and need for support in pursuit of independent adulthood: fragile social relationships, illness/issues with mental health and moving residence. These themes illustrate how young people's paths to adulthood and their orientations to the future are constrained by biographical factors which impact their investments and sense of competence and direct their access to material, social and emotional resources that can help them to build independent adult lives (Thomson et al. 2004; Thomson 2007). They also provide insights on how young people relate to the events and experiences in their immediate relationships and social environments. Even though these themes do not include all the biographical factors associated with the struggle for independence in our research material, many of the events that interviewees themselves identified as 'critical moments' in their lifelines intertwined with one or more of these themes.

\section{Fragile family and intimate relationships}

Most of the life stories were marked by fragile family relationships and lack of care, security and support. Unpredictable events and discontinuities in social relations, such as illness or death of a parent or friend, were common and had resulted in unforeseeable consequences for young people's transitions (MacDonald and Shildrick 2013). Due to the insecurities in their social lives, sometimes persistent since childhood, many interviewees reported trust building issues. Moreover, difficult family situations caused many of them to leave their childhood homes early in comparison to their peers. 
We observed different dynamics in social relations, ranging from loud arguments and conflicts to remaining quiet and feeling of emotional distance or of being left alone. Emilia (aged 20) used to quarrel with her mother. She narrated:

It was a Friday evening in 2015. I was 16 . We had a really miserable relationship with my mother. We did not get along and she threw me out of the house that Friday evening. I had a mobile phone, and I drove with my motorbike to the woods and thought there what to do. Finally, I found this place [YS] on the web, and finally, I stayed there.

Emilia remembered that relations between herself and her mother had become strained after she started seventh grade. She was the oldest of the siblings and felt that her mother was always reprimanding her. According to Emilia, it was actually her mother who had told her to move out during their arguments. Her father lived abroad, and she did not know her grandparents. Furthermore, their family had lived abroad because of her father's work and she had not built enduring relationships in Finland. At the time of crisis, she did not know where to go or who to turn to. 'There were no safe adults or anyone like that in my life at that time', she related. Emilia's observations and experiences reveal that in order to feel secure, it is necessary to know people one could rely on and ask for support. Moving from one place or country to another can leave a young person without the much-needed social network required for such a transition.

Sara (21 years) also reported having arguments with her mother.

I was 18 at the time. My boyfriend at the time also lived at our place. We had a somewhat unbalanced situation at home because my mother had just taken her ex back. I did not get along with my mother's ex and (...) [f]inally, the ex, who had not even moved back to our place, kicked my boyfriend out of the house (...) We fought all the time with my mother and I was also concerned about my sisters. Mum was working 24/7. I went to the web and clicked on a button and got a call from here [YS]. I came to the crises section and as my boyfriend had been thrown out, I had decided that I will move out also.

Sara's account highlighted her tensions with her mother and her mother's spouse. Sara felt that her mother was working all the time, and she was worried about her younger sisters' wellbeing and physical integrity.

These accounts contradict the normative life course narrative, which typically includes the presence of a childhood family, usually with one's biological parents, and thereby securing one's material, social and emotional being (cf. Jones 2009, p. 163). Instead of the satisfactory support required during their growing-up years, the young adults highlighted instability in family relations due to separation, death and problems with money or intoxicants, for instance. Sometimes, lack of parenting resulted from a parent falling short of 
resources because of his/her own problems or difficulties with other family members. Nikki (19 years) related how she had not learnt social skills at home.

Well, I think that my past is a very relevant matter in relation to my independence. See, I come from a bit of a bad family. There were problems with alcohol, I was not allowed to go out and nobody could come to our place ... as if I was not allowed to be visible and heard. I did not learn those normal skills required for independence, let alone social skills, at all.

These feelings of 'invisibility', loneliness and not getting recognized were also present in the other interviewees' accounts. For example, after the sudden death of her father, Veera (aged 20) felt that she had mainly become a babysitter for her younger siblings in a reconstituted family.

In addition to family relations, peers and romantic relationships played a significant role in young adults' lives. Many had struggled for years with selfesteem and trust issues because of the bullying they had experienced at school. Valtteri (24 years) contacted the YS because he had become homeless after breaking up with his short-term girlfriend with whom he had shared an apartment. He did not maintain contact with his mother, and his father had died when he was 6 years old. His grandmother was dead too. He himself had a little daughter whom he had not seen. When Valtteri and his mother moved to a new town, he did not stay there long. He left alone to return to the place he had moved from because his friends lived there. Eventually, he was enrolled in child care services at the age of 16. Like Emilia, Valtteri did not have close relationships with his childhood family, and all his brothers and sisters had been moved to foster homes.

Fragile family relationships and tensions or the experience of being ignored at home sometimes resulted in accelerated steps toward independence and leaving of the childhood home, highlighting the need to find meaning and support from other social relationships. In most cases, the young adults' reflection on their frail relations, wellbeing and resources with regard to initiating independent living were related and emphasized their need for support. A few interview accounts nevertheless depicted family relations as unproblematic and unrelated with support needs such as requiring help with life management or acquiring an apartment. Moreover, despite some history of family problems, a few interviewees narrated that their parents had supported their process of independence by helping with living arrangements, for instance. Some had come to the YS with a parent or due to the parent's advice.

\section{Illness and psycho-social wellbeing issues}

While health concerns as such were not a reason for these young people to contact the YS, they overlapped intricately with their life stories and current 
challenges. In addition to their own health problems, many had encountered illness and bereavement in their immediate social relationships, which were often conveyed in the interviews in a mundane manner although they struck us, the interviewers, as out of the ordinary and distressing (MacDonald and Shildrick 2013). The most common type of ill-health issue recounted by the youngsters themselves was depression, which was often associated with anxiety or other mental health problems.

Viivi (24 years) had entered the Kotipolku Project via access to outreach youth work $^{14}$ in the midst of her move from one house to another; she was not able to find a new home as quickly as she had hoped. She had been simultaneously seeking a place for a work experiment or rehabilitation. Viivi related her difficulties with her health issues which were also intertwined with her social relations.

I had been diagnosed with Asperger later in my life, and I feel that it is the reason why I have had all kinds of problems. When I was 16, I looked for psychiatric help for the first time. I think there were multiple issues, such as little sisters and a new living place after moving to a new town. After moving I realized that I was unwell in some way. I was stuck. I had no means of going forward and I did not know what was wrong.

Anni (22 years) told us about her rheumatism.

I went to study to become a waitress although its [rheumatism's] symptoms were apparent. I never had to stay away from school because of rheumatism although we had almost one year of work practice. Of course, there were periods during my leisure time when I was more sick and more tired than usual and I had occasional pains.

Her rheumatism had required attention throughout her life. She had tried many different medications, because some of them had resulted in sideeffects. In addition to rheumatism, she was diagnosed with depression in secondary school.

I had anxiety and depression, and I used to cut myself. Well, my mother noticed and contacted the school nurse who guided me to a city youth psychiatric centre. I went a lot to therapy; however, I was able to go to school. My workload at school was reduced by $20 \%$ and I was allowed to come to the school later so that I could sleep enough. I used to stay up and cry, so of course, I was tired in the morning.

The manner in which people categorize and experience certain events depends on their social environments (Thomson et al. 2002, p. 342). Viivi's narrative indicates that she remained confused and was unable to solve issues and 'go forward'. She felt that one reason for her problems was the developmental disorder, which affected nonverbal communication and caused difficulties in 
social interaction since school age. At home, she did not want to burden already tired parents with her own problems; instead, she suffered quietly and retreated into herself.

The youngsters we interviewed puzzled about how they would manage in their work lives because of their struggles with disorders, depression and other mental health problems, illnesses, medication requirements and hospital visits, all of which could disrupt their attention at school. For example, Anni's narrative demonstrated how helping someone with an illness to recover requires the attention of not just the person undergoing that illness, but also his/her family, friends and institutions.

In addition to illnesses and disorders, some of the young adults confessed to problems with substance use. For example, Valtteri had been partaking alcohol and other intoxicants from secondary school onwards. After completing basic education, he had attended school only irregularly because of his alcohol use and the requirement to travel between the town the school was located in and the town in which his friends resided. He used to drink alcohol with his friends and consequently skipped school. Interviewed at the age of 24 , he was studying in vocational education and training. He regretted 'missing' so many years of his early adulthood because of a reckless lifestyle resulting from his early freedom that independent living resulted in after his leaving care. 'But then, it can't be changed. Forward, forward', he said.

Aleksi (aged 21), who received his own home via the Kotipolku Project, explained the following:

Well, I am in a messed up situation. All kinds of things have happened recently. Last summer, I left the army. Then I worked for a while ... I do not know ... I was distressed about everything and I lost interest in life. Well then I started to use drugs. I had to go to the rehabilitation but I did not stay there. It was too short a visit.

Aleksi had quit military service after a short while, disappointing his father, who had told Aleksi that he should not come home and instead live elsewhere. He had then moved in with his sibling, and his mother had helped him to contact the YS Project in order to find a place of his own. Aleksi's drug use seemed to be related to his feeling of not knowing what to do. He was unable to agree to long-term commitments required for the military, a working life and rehabilitation.

Overcoming an illness requires specific attention and care, and, as in the case of substance use, these efforts take time away from school, which is a crucial institutional marker of life transitions. The interview accounts also show how young adults negotiated their everyday life in poor health conditions, which arose from their difficult transition experiences and complicated their social activities and their relations with the welfare service system. On the other hand, substance use appeared to offer some form of sociability, which the young people found more appealing in their life situations, particularly when their institutional duties were stressful or difficult to deal with. 


\section{Moving residence}

The third unifying theme in the young interviewees' narratives of seeking support at the YS involved physically moving from one town or neighbourhood to another or out of their childhood homes. These young people moved for different reasons, and sometimes, the moving was dictated-even forcedby external factors. Notably, moving to one's own home was configured as a turning point in the process of independence for the interviewees, who reported experiencing mixed feelings and practical challenges. Jerome, who stayed at the YS for some time while waiting to get his own apartment after having moved to town, felt that having a place to call his own had been a starting point for his new life and helped to solve some of his troubles. For Nora, moving into her own home made life easier as she escaped from the violent atmosphere of her childhood home.

The moving went well. I lived in this town and went to school in another. Sometimes, it took as much as two hours to travel to the school. The moving helped the travel-related stress and I did not have that feeling of responsibility that I had experienced in my [childhood] family. I was allowed to be independent. I only had to take care of the apartment.

Although Nora experienced struggles at the beginning of her independent living phase (we will explore these later in this chapter), she felt that living alone helped her to concentrate on her studies and her life in general.

The young adults reported struggles with the support system, as they were unaware about how to navigate it. These issues resulted in problems with money and paying rent. Some expected that their moving to live alone meant that they would decide every aspect of their lives as they pleased and would live exactly as they wished. However, they found their daily routines in disarray and resorted to binge-watching movies and programmes online, much like the practice in their childhood homes.

Young people who immigrate to Finland alone when under-aged experience mixed feelings of hope and despair as well as opportunities, uncertainties and responsibilities (Honkasalo et al. 2017, p. 7). Moreover, some have had to move several times within Finland and adapt to changing locations and social relationships on each such occasion. Jusuf (21 years), for example, had moved four times during the four years he had stayed in Finland.

I came to Finland in 2015 and I lived in a town in eastern Finland. Then I moved to a different town to study the Finnish language, but I did not have many friends there. Then my social workers told me that I had too long a way to travel to school and so I moved to a new town in eastern Finland. It was better in that town because it contained people from the same country I had belonged to.

His narrative revealed that in the beginning of his stay in Finland, his life was structured and conditioned by Finnish laws and institutions. In accordance with observations from studies focusing on young asylum seekers, Jusuf's 
movements from one centre to another or to a school housing were suggested by his social workers (Piitulainen 2016, pp. 17-18), and he felt that he had made more friends after moving to a bigger town, where he was able to play football with them in his free time (Maiche 2017, p. 22). These accounts also suggest that institutions and official networks may not always work in the best interests of the young person or fail to provide adequate support, especially to children or young adults who are trying to plan their future without recourse to trusted intimate relationships.

Aada moved away from her childhood home at the age of 16 to escape an extreme situation; she was fleeing from a personal threat. This was the first time she had moved homes after having lived for some periods in a hospital ward. Once she was alone in her student flat in the new town, she was shocked by the lack of friends and loneliness and became depressed because she had no one to turn to. After relocation, she maintained contact with the outreach youth workers and the adolescent psychiatric clinic that had directed her to the YS. She needed support mainly because of the intimidation which continued despite her changing homes, which made her feel afraid to move out alone. She was sometimes escorted to the YS from her home by car. The start of her independent life included a difficult study year with many absences from school, which was partly exacerbated by sleep problems confusing her daily rhythm.

An exploration of the various reasons for entering the YS revealed that obstacles to independent living, such as homelessness, often result from diverse dynamics and accumulated troubles associated with social relations, health issues and/or encounters with institutional structures, such as the service system. For most of our interviewees, these experiences and dealing with them had created delays and twists and turns in transitions in education and from school to work. They recognized that these issues affected their possibilities to make choices and long-term plans in different areas of life and made them dependent on external support, often against their will, increasing uncertainty about their own abilities and future prospects. For some of the interviewees, moving to the big cities of southern Finland had temporarily added to challenges of managing personal life but also had helped to find a combination of services where one's support needs were met.

\section{Enabling spaces and possibilities for support}

The focus on the YS as a critical moment in the youngsters' biographies highlights the kinds of help the young adults needed and found useful in their quest to live independently. It draws attention to the role of professionals and different aspects of the service system as part of young people's life stories and thus contribute to improved understanding of more opportunities for providing support (Thomson 2007, p. 73, 104).

As pointed out earlier, the Finnish support system is diverse and includes public, private and third sector services. The interviewees, who had been involved in several services with different sectors, had accumulated both 
positive and negative experiences of service encounters. They pointed out aspects that had not worked well for them, such as situations when there was confusion about service provision or when there was a break in provision (Munford and Sanders 2016). In this section, based on the young adults' narratives, we highlight the assistance they found helpful in their life situations and in relation to their future plans.

One of the recognized problems within the Finnish support system involves its fragmentation (Perälä et al. 2012). Viivi had become aware of this fragmentation when she had moved from one place to another.

The worst experience in mental health care was when I moved [to a different town]. I was on a sick leave at the time. They wrote me an admission note stating that my sick leave should be continued. I came to the new place and started the therapy. My papers had not arrived at that time. Then, my papers arrived and the therapist told me that you do not belong here, go away, we are not a bank, go to work. That was the most negative experience that I have ever had and nobody helped. I was like, well, where do I go?

Viivi remembered this experience as 'the worst one'. She had moved to a new place and was abandoned without support. She had just lost her apartment in the town she previously lived in. Eventually, she lived with her previous roommate for half a year, and in her own words, 'twiddled [her] thumbs and just wondered what I am going to do now. Everything collapsed and I stayed out'.

The fragmentation and overlapping of services over different sectors or municipalities weakens their influence due to problems with information transfer and the provision of the services by only one sector (Pekkarinen and Myllyniemi 2012, pp. 26-27; Perälä et al. 2012). These oversights lead to situations in which only the symptoms are treated, while the actual problems persist. In addition, some cases do not receive any assistance at all, as in Viivi's example. Her words describe how the existing everyday structures and practices 'collapsed', a word often used in situations when people's experiences change (Lawler 2010). Viivi felt excluded, was not able to do much and was forced to stay 'outside'. This kind of support structure excludes certain people, and also maintains inequalities and divisions between those inside and the others outside it (Saari 2019, p. 24). Finally, in geographical terms too, the support system is uneven. For example, when Viivi relocated to the urban capital area, she felt that the doctors there possessed the professional experience to help her.

In general, the young adults described that the YS had supported them and their everyday coping concretely by providing temporary accommodation, helping them to fill the different forms required by the bureaucratic system or advising them on carefully managing their salary, study allowance or living expenses. The young adults also mentioned that they had been able to discuss their life situations, possibilities and future hopes honestly at the YS. 
The young people's reflections, however, showed that they lacked concrete knowledge of the workings of the support system, the kinds of support available to them and their rights (see also Kulmala and Fomina, this volume). Nora explained that she was quite lost as to how things in her life should work.

Clearly, I was not able to handle all that is required when one is independent; money for rent, water and electricity bills, telephone, food and clothes ... everything. I wanted someone who had gone through the same things to advise me on what to do.

The importance of concrete and practical support was also highlighted by Emilia.

I got help from here [YS] with money issues, like with an alimony, and do I have any possibility to apply for some monetary support ... I did not know anything about those things ... We filled in applications for KELA ${ }^{15}$ and copied them together (...) And everybody were really friendly here and I got all the stamps and envelopes.

Researchers have pointed out that the institutional system itself can marginalize young people: understanding the service system requires multiple skills, time management, flexibility and the patience to wait one's turn (Aaltonen et al. 2015; Brunila et al. 2018). In addition, people with difficulties are often quiet and have been silenced (Aaltonen and Kivijärvi 2017, p. 17; Atkinson et al. 2003, pp. 71-72). Indeed, the young adults highlighted situations where they had remained quiet although they were unsure about whether their affairs had been handled well by the experts. Anni explained how her visits to the rheumatism clinic were not always pleasant.

I did not get what I wanted or what belonged to me at the doctor's. I always felt that we disagreed with the doctor, and because I was a young girl, I always left with the feeling that everything is not well, and I called crying to my mum that I don't know what I will do.

The service system is built on the assumption that individuals who seek assistance are able and willing to talk and describe their situations. For example, Aada reported that she was only able to talk about her issues with the psychiatrist after seeing them over a longer time period: 'When I did not know how to talk, there was no point of going there.' Valtteri stated that, 'One gets help when one asks', emphasizing the importance of asking for the required service and support, and sometimes, even knowing what to ask.

In spite of their negative experiences, the young adults themselves offered ideas for relevant support. A very concrete and practical suggestion came from Nora, who suggested that civic skills should be taught in elementary school: 'They should teach very practical civics in comprehensive school. Like how to fill in KELA forms.' 
In addition to the practical help, the YS supported the young adults by their very presence, discussing their lives, thoughts, fears, hopes and plans. As Emilia put it,

... and the most important thing was that when I said something, the people [at the YS] did not just agree with me; they were able to argue against me and discuss the issue from different perspectives ... It was important that they listened but did not pet one's head. And when I called here, it did not have to be for some really devastating event and I was still allowed to come here. That was important.

These reflections show that the young people appreciated the concrete and holistic support that the official sector-based service system of the welfare state may not always be able to provide. The young adults appreciated talking, listening and being offered diverse and realistic perspectives. These perspectives were not only related to their work or educational plans, but also concerned their identities, competencies, social relations, the kinds of lives they wanted to live and the possibilities.

Simply being aware that a safe alternative such as the YS existed for young adults to contact at any time improved their feelings of security. Pinja, who had been provided child protection under social services and later moved from the hospital to live by herself, described the following:

It was important that the support was not tied to the office hours. In addition, it was not always about problem solving but just hanging around, being quiet or chatting about everyday matters. It was important to know that there was a place that one could contact and go, even if one was living by himself/herself.

In addition to knowing that the support was not restricted to office hours, the fact that the YS provided a relaxing atmosphere that allowed socializing and did not necessarily include problem solving was considered to be very relieving. When needed, the YS served as a temporary, safe and drug-free accommodation between 5 p.m. and 10 a.m. daily, and many of the interviewees had made use of these facilities. Unlike the Russian care leavers interviewed by Kulmala and Fomina (this volume), who experienced their targeted services as stigmatizing, the participants in our study did not discuss social stigma in association with the YS, which are open and accessible to anyone.

The narratives of the young adults also inform us that the safe and reliable workers they found at the YS strengthened their ability to cope during difficult life situations, supported their life choices and increased their sense of safety. The employees of the YS were significant adults who could provide the young people with alternative perspectives of difficult situations and life in general, helping them to recognize new aspects of themselves and believe in their dreams and the possibility of building their own lives (see also Kulmala and Fomina, this volume). At the same time and according to the 
YS ethos, many young people felt they had been able to re-connect and build a more positive rapport with their parents. The positive accounts of getting help from the YS thus point to the young adults' subjective experiences of being recognized as people with their own personalities, special needs and life situations, and not only in terms of their problems.

Our data also show how young adults became familiar with fragmented services and project-like working lives through their contacts with the support system (cf., e.g., Puuronen 2014a, p. 30). Viivi noted,

I would like to complain about project work because most of the help that I get at the moment from The Girls House and outreach youth work is paid as projects. I have been talking with these workers, and in both cases, the relationships with them ended because their project funding had ended.

The young adults felt that it was tiring to establish new relationships with new people. As Anni described: 'I am tired of explaining my situation over and over again and getting to know new people as people [in the services and support system] change ... it is just so $\mathrm{f}^{* * * * * *}$ tiring'.

The young adults' reflections show that they appreciated long-term relations with support personnel (Gissler et al. 2018). It was important for them that one or more adults know about their situations. However, not all the workers and young people got along. Jerome indicated that he told the YS volunteers 'I do not like you' upon recognizing that he did not get along with them. Jerome was able to express his boundaries despite the challenges he had confronted as he had come to Finland alone as a young teenager. Such a comment and the underlying need to draw boundaries informs us about agency that tends to be restricted and controlled in the institutional service context (Foucault 2005; Goffman 1969; Honkatukia et al. 2020, pp. 54-55; Kallio 2019, p. 169). It demonstrates the importance for young people to be allowed to express themselves and to be heard and thus maintain their autonomy in navigating the services and managing themselves.

\section{Conclusions}

Researchers in youth studies have called for more nuanced accounts of the manner in which young people's experiences in different spheres of life, and in relation to services, interact (Aapola and Ketokivi 2005; MacDonald and Shildrick 2007; Thomson 2007; Suurpää 2009; Aaltonen and Kivijärvi 2017). In this chapter, we focused on biographical interviews that captured the dynamic processes of independence and experiences of young people on the threshold of adulthood who are typically targets of policy interventions and whose voices are not so well heard in the society (cf. MacDonald and Shildrick 2018). As in the case of the youth population in general, the study participants were a diverse group of people from different social backgrounds, some more committed to society than others. Their struggles of independence are 
not unique to Finland; they run parallel with the lives of the youths in other Nordic countries (e.g. Ekman 2020, p. 2; Paulsen et al. 2018; Jørgensen et al. 2019). Thus, despite the local data analysis and framework setting, the study contributes to a wider debate and policy emphases on young people's wellbeing and opportunities for meaningful citizen engagement in the context of social sustainability. Our observations also resonate with those of Kulmala and Fomina in this book, addressing, in a different cultural context, how young adult's agency is informed by social circumstances and negotiated at the junction of the past, present and future.

The biographical perspective illustrates how the social conditions of growing up shape young people's wellbeing and how unpredicted life events or insecure social relationships may impact on their chances of building independent lives. At the same time, it helps to identify the characteristics that shape contemporary transitions to adulthood more generally. We focused on the significance of the YS as a 'moment' in each of our interviewees' life courses, which is 'critical' given its consequences on their lives and identities as well as its revelations of the needs topical in the life stage of emerging independence and the kinds of support the young adults found appropriate. Our analysis of the YS as a 'critical moment' also highlights the importance of safe adult relationships and sound emotional support on the way to independent living and points to the possibility of providing an emotional social safety net.

The young interviewees' motivations to seek help at the YS and their support needs varied depending on the specific issues affecting them, such as finding a residence, searching for more long-term support with everyday life management or seeking psycho-social wellbeing (e.g. self-confidence or a sense of security). In addition to family background and other immediate relationships, their challenges were influenced by health issues and the changes associated with moving from one location to another. ${ }^{16}$ As these various issues were often intertwined and had been accumulating over the years, their challenging life situations could not be set right with short-term solutions and a narrow approach to defining problems. It seems, nevertheless, that the youths' sense of autonomy and competence benefited from the support and nurturing provided by the YS, which granted them time to resolve their issues and a low threshold for seeking aid. In doing so, the system recognized a person in his/her specific social circumstances.

One of the most prominent features in our data concerned the fragility of social relationships defining the transition to adulthood. Many of the interviewees had suffered from bullying at school or had taken responsibility for themselves, and sometimes even their younger siblings, at an early age. Tellingly, most of them acknowledged the significance of reliable adults and impartial space at the YS, where they could think about their identities and take steps towards independent living. Despite their familiarity with the other welfare services, they noted that the kind of practical and emotional support provided by the YS was essential to their wellbeing. As per many interviewees' life narratives, their affiliations to the YS signified positive change and personal growth. 
According to our findings, health concerns and health-related behaviours, which have not been studied as key strands influencing youth transitions (MacDonald and Shildrick 2013), require particular attention as part of the current day processes of independence in terms of how the personal struggle and social disadvantage related to health problems interact with social structures and the uncertainties in youths' lives (Brunila et al. 2020; Brunila and Lundahl 2020). Mental health problems, which are sometimes associated with other illnesses or addiction, were prominent in our data. They required active attention from the young people, influencing both their investments and sense of agency in different spheres of life, and reducing their possibilities for smooth transitions from education to work and independent living. Depression, for example, which is increasingly diagnosed among the youth (Filatova et al. 2019), both reflects and adds to anxieties about the work life and is therefore related to social expectations and pressures targeting young people.

According to our data, the subjective sense of managing by oneself lies at the core of achieving independence for young people (Honkatukia et al. 2020). However, becoming independent is not a transition towards being selfsufficient; instead, it involves the reshaping of the social relationships and mutual dependencies between people (Cameron et al. 2018). Our findings show that the YS workers had an important role in helping the young people to strengthen social ties in their lives. Moreover, the young adults' appreciation of the holistic encounters at the YS suggests that to support wellbeing and independent coping, a third sector service based on voluntary engagement may be able to provide a sense of personal recognition and timely support in a way that the fragmented, often burdened government services cannot necessarily offer. Importantly, these service encounters had allowed the young people to regard themselves as socially included and competent adults who have resources and capabilities for coping (see also Thomson et al. 2004; Juvonen 2015; Munford and Sanders 2016; Gissler et al. 2018).

Altogether, our study highlights the need for more flexible and holistic forms of services for Finnish youth transitioning to independent living compared to the simple focus on quick moves through education to working life. Improved biographical understanding based on the views and experiences of the young adults themselves and their accounts of the diverse paths towards adulthood could provide insights into developing practices to support young adults in their quest for independence.

\section{Acknowledgements}

We are especially thankful to all the young people who took part in our study as well as the staff members of Red Cross Youth Shelters who helped us with the recruitment of the study participants. We are also grateful to the editors of the book, other reviewers of the manuscript and Päivi Honkatukia for their insights. We thank Stefan Kirchner for his help and expertise in German social law. The research was funded by the Strategic Research Council at the Academy of Finland under the ALL-YOUTH Project (decision no. 312689). 


\section{Notes}

1 A crucial change for a small proportion of youth involves the end of the statutory right to alternative care. This change permits after-care with a personal service plan, the age limit of which was recently changed from 21 to 25 years by the amendment to the Finnish Child Welfare Act (Sosiaali- ja terveysministeriö, 2020).

2 In Finland, child benefit ends when a person turns 17, while the German model, for example, allows parents, under certain terms, to continue applying for the child benefit until the child turns 25 (Bundeskindergeldgesetz 2009).

$3 \mathrm{https} / / / \mathrm{www}$. redcross.fi/help-and-support/support-emergency-youth-shelter

4 In 2018, the Youth Shelters supported 1,054 young adults and 1,791 parents. They served 5,370 individual, parent, or network negotiations (Nuorten turvatalon vuosi 2018: 5).

5 The Kotipolku Project was launched in 2018 as a response to an increasingly difficult housing situation for young adults under 25 years in the capital metropolitan area (Kotipolku 2020).

6 Julie Cruikshank (1998) coined the term 'epitomizing event' in the context of oral history studies in anthropology. She also worked with biographical narratives as a research method.

7 We made our own assumptions based on the interviewees' names and selfpresentations. We did not ask them about their gender identification preferences unless the issue was brought up by the interviewee.

8 The young adults were contacted by a worker of the YS, who presented the initial interview request. Only persons aged over 18 years were contacted.

9 We are ethically committed to protect the privacy of the interviewees and avoid any harm to them. Thus, locations other than the capital metropolitan area (Helsinki, Espoo and Vantaa) are unspecified, and instead, we refer to 'big city' or larger areas (e.g. 'eastern Finland').

10 Almost two-thirds of the research participants were women even though about half of those who reach out to the YS are male. Despite the staff's efforts to motivate young men to participate, many rejected the opportunity.

11 These concerns were reflected throughout our recruitment and research process. We ensured that the interviewees were aware of their rights, as well as the availability of the YS staff to discuss any aspect of the interview that might upset them. Ethical approval was obtained from the Tampere University Research Ethics Committee. Informed consent was given by the participants after all the steps of the procedure were explained to them.

12 These central research themes were participation in society, relationship with societal institutions, social relations and the importance of (one's own) home.

13 As our definition of critical moments (or the turning points in each account) encompasses both events and experiences emphasized by the young people themselves and what we as researchers identified as critical, it is important to note that these two may differ (Thomson and Holland, 2015: 727).

14 Outreach youth work in Finland takes place under regional state administrative agencies and expands on youth work by reaching youth under 29 years old in their own surroundings. It is a 'detective form' of youth work, which seeks to identify needs for services and supports their delivery with a youth-centred ethos (Puuronen 2014b).

15 KELA refers to the Social Insurance Institution of Finland. 
16 There were also other social or socio-structural factors, which influenced some of these young people's challenges of independence such as discrimination based on ethnicity and racialized identity.

\section{References}

Aaltonen, S., Berg, P. and Ikäheimo, S. (2015) Nuoret luukulla-Kolme näkökulmaa syrjäytymiseen ja nuorten asemaan palvelujärjestelmässä. Nuorisotutkimusseuran/ Nuorisotutkimusverkoston julkaisuja 160. Helsinki: Nuorisotutkimusverkosto/ Nuorisotutkimusseura.

Aaltonen, S. and Kivijärvi, A. (2017) Nuoret aikuiset hyvinvointipalvelujen käyttäjinä ja kohteina [Young adults as users and objects of welfare services]. Nuorisotutkimusseuran/Nuorisotutkimusverkoston julkaisuja 198. Helsinki: Nuorisotutkimusverkosto/Nuorisotutkimusseura.

Aaltonen, S., Kivijärvi, A. and Myllylä, M. (2018) Työn ja koulutuksen ulkopuolella olevien nuorten aikuisten koettu hyvinvointi. Yhteiskuntapolitiikka 84 (3), pp. 301-311. Available at: http://urn.fi/URN:NBN:fi-fe2018110147048.

Aapola, S. and Ketokivi, K. (2005) Polkuja ja poikkeamia - Aikuisuutta etsimässä [On and off the beaten tracks - searching for adulthood]. Nuorisotutkimusseuran julkaisuja 56. Helsinki: Nuorisotutkimusseura.

Aapola-Kari, S. and Wrede-Jäntti, M. (2017) 'Perinteisiä toiveita, nykyhetkeen kiinnittyviä pelkoja-nuoret pohtivat tulevaisuutta', in Myllyniemi, S. (eds) Katse tulevaisuudessa: Nuorisobarometri 2016. Valtion nuorisoneuvoston julkaisuja, 56, pp. $159-176$.

Arnett, J. J. (2000) 'Emerging adulthood: A theory of development from the late teens through the twenties', American Psychologist, 55(5), pp. 469-480. doi: 10.1037/0003066X.55.5.469.

Arnett, J. J. (2001) 'Conceptions of the transition to adulthood: Perspectives from adolescence through midlife', Journal of Adult Development, 8(2), pp. 133-142. doi: 10.1023/A:1026450103225.

Atkinson, P., Coffey, A. and Delamont, S. (2003) Key themes in qualitative research: Continuities and changes. Walnut Creek: Rowman Altamira.

Beck, U., (1992) ' From industrial society to the risk society: Questions of survival, social structure and ecological enlightenment', Theory, culture \& society, 9 (1), pp. 97-123.

Berngruber, A. (2016) 'Leaving the parental home as a transition marker to adulthood', in Furlong, A. (eds) Routledge handbook of youth and young adulthood. 2nd edn. New York: Routledge, pp. 209-214.

Blatterer, H. (2007/2009) Coming of age in times of uncertainty. New York: Berghahn Books.

Brunila, K., Hakala, K., Lahelma, E. and Teittinen, A. (2013) 'Avauksia ammatilliseen koulutukseen ja yhteiskunnallisiin erontekoihin', in Brunila, K., Hakala, K., Lahelma, E. and Teittinen, A. (eds) Ammatillinen koulutus ja yhteiskunnalliset eronteot. Gaudeamus Helsinki University Press, pp. 9-16.

Brunila, K., Honkasilta, J., Ikävalko, E., Lanas, M., Masoud, A., Mertanen, K. and Mäkelä, K. (2020) 'The Cultivation of Subjectivity of Young People in Youth Support Systems', in Nehring, D., Madsen, O. J., Cabanas, E., Mills, C. and Kerrigan, D. (eds) The Routledge International Handbook of global therapeutic cultures. Abingdon, Oxon: Routledge. doi: 10.4324/9780429024764. 
Brunila, K. and Lundahl, L. (2020) 'Introduction', in Brunila, K. and Lundahl, L. (eds) Youth on the move: Tendencies and tensions in youth policies and practices. Helsinki: Helsinki University Press, pp. 1-14. doi: 10.33134/HUP-3-1.

Brunila, K., Mertanen, K., Ikävalko, E., Kurki, T., Honkasilta, J., Lanas, M., Leiviskä, A., Masoud, A., Mäkelä, K. and Fernström, P. (2019) 'Nuoret ja tukijärjestelmät haavoittuvuuden eetoksessa', Kasvatus, 50(2), pp. 107-119. Available at: http://urn. fi/URN:NBN:fi:ELE-017380263.

Brunila, K., Mertanen, K., Tiainen, K., Kurki, T., Masoud, A., Mäkelä, K. and Ikävalko, E. (2018) 'Essay. Vulnerabilizing young people: Interrupting the ethos of vulnerability, the neoliberal rationality, and the precision education governance', Journal of the Finnish Anthropological Society, 43(3), pp. 113-120. doi: 10.30676/ jfas.v43i3.82737.

Bundeskindergeldgesetz (BKGG) [Federal Child Benefit Law] of 28 January 2009, Bundesgesetzblatt (BGB1.) [Federal Gazette] 2009 I 142 and 2009 I 3177, as amended by Article 5 of the Law of 1 December 2020, Bundesgesetzblat 2020 I 2616. Availableat:https://www.gesetze-im-internet.de/bkgg_1996/BJNR137800995. html\#: : text $=\mathrm{Im} \% 20 \mathrm{Fall} \% 20 \mathrm{des} \% 20 \% \mathrm{C} 2 \% \mathrm{~A} 7 \% 202$, Lebensjahres $\% 20$ gew $\%$ C3\%A4hrt (Accessed: December 8 2020).

Cameron, C., Hollingworth, K., Schoon, I., van Santen, E., Schröer, W., Ristikari, T., Heino, T. and Pekkarinen, E. (2018) 'Care leavers in early adulthood: How do they fare in Britain, Finland and Germany?', Children and Youth Services Review, 87, pp. 163-172. doi: 10.1016/j.childyouth.2018.02.031.

Cruikshank, J. (1998) The social life of stories: Narrative and knowledge in the Yukon Territory. Lincoln and London: University of Nebraska Press.

Du Bois-Reymond, M. (1998) 'I don't want to commit myself yet': Young people's life concepts', Journal of Youth Studies, 1(1), pp. 63-79. doi: 10.1080/13676261. 1998.10592995.

Ekman, T. (2020) Country sheet on youth policy in Sweden. Partnership between the European Union and the Council of Europe in the field of youth. Available at: https:// pjp-eu.coe.int/documents/42128013/63134234/Sweden_Country-sheet_April2020. pdf/835bf2e1-674c-e117-590a-55f673e08c72 (Accessed December 15 2020).

Elder, G., Jr. (1994) 'Time, human agency, and social change: Perspectives on the life course', Social Psychology Quarterly, 57 (1), pp. 4-15. doi: doi:10.2307/2786971.

EUROSTAT, (2019) When are they ready to leave the nest? Available at: https:// ec.europa.eu/eurostat/web/products-eurostat-news/-/EDN-20190514-1 (Accessed: May 15 2020).

Filatova, S., Upadhyaya, S., Kronström, K., Suominen, A., Chudal, R., Luntamo, T., Sourander, A. and Gyllenberg, D. (2019) 'Time trends in the incidence of diagnosed depression among people aged 5-25 years living in Finland 1995-2012', Nordic Journalof Psychiatry,73(8),pp.475-481.doi:10.1080/08039488.2019.1652342.

Foucault, M. (2005/1975) Tarkkailla ja rangaista. Keuruu: Otavan Kirjapaino Oy. Original Michel Foucault (1975) Surveiller et punir: Naissance de la prison. Paris: Gallimard.

Furlong, A. (2013) Youth studies: An introduction. London: Routledge.

Furlong, A. and Cartmel, F. (2007) Young people and social change: New perspectives. 2nd edn. Maidenhead: Open University Press.

Giddens, A. (1991) Modernity and self-identity: Self and society in the late modern age. Stanford: Stanford University Press.

Gissler, M., Kekkonen, M. and Känkänen, P. (2018) Nuoret palveluiden pauloissa: Nuorten elinolot -vuosikirja 2018 [Tangling with the services: Young people's living 
conditions - yearbook 2018]. Helsinki: Terveyden ja hyvinvoinnin laitos. doi: http:// urn.fi/URN:ISBN:978-952-343-200-0.

Goffman, E. (1969) Minuuden riistäjät. Tutkielma totaalisista laitoksista. Helsinki: Marraskuun liike. Original Goffman, E. (1961) Asylums: Essays on the social situation of mental patients and other inmates. New York: Anchor Books.

Henderson, S., Holland, J., McGrellis, S., Sharpe, S. and Thomson, R. (2007) Inventing adulthoods. A biographical approach to youth transitions. London: Sage.

Hiilamo, H. and Saari, J. (2010) Hyvinvoinnin uusi politiikka: johdatus sosiaalisiin mahdollisuuksiin. Diakonia-ammattikorkeakoulun julkaisuja. Tampere: Juvenes Print Oy.

Hoikkala, T. (1993) Katoaako kasvatus, himmeneekö aikuisuus? Aikuistumisen puhe ja kulttuurimallit. Helsinki: Gaudeamus.

Honkasalo, V., Maiche, K., Onodera, H., Peltola, M. and Suurpää, L. (2017) 'Johdanto', in Honkasalo, V., Maiche, K., Onodera, H., Peltola, M. and Suurpää, L. (eds) Nuorten turvapaikanhakijoiden elämää vastaanottovaiheessa. Nuorisotutkimusverkosto/Nuorisotutkimusseura Verkkojulkaisuja 2016 (120), pp. 7-8. Available at: http://www.nuorisotutkimusseura.fi/images/julkaisuja/nuorten_turvapaikanhakijoiden_elamaa_vastaanottovaiheessa.pdf (Accessed: August 30 2020).

Honkatukia, P., Kallio, J., Lähde, M. and Mölkänen, J. (2020) Omana itsenä osa yhteiskuntaa: Itsenäistyvät nuoret aikuiset kansalaisina. [A part of society in one's own right - Young adults becoming independent as citizens] University of Tampere: Faculty of Social Sciences. Available at: http://urn.fi/URN:ISBN:978-952-03-1731-7 (Accessed: December 9 2020).

Jones, G. (2009) Youth. Cambridge: Polity Press.

Jørgensen, C. H., Järvinen, T. and Lundahl, L. (2019) 'A Nordic transition regime? Policies for school-to-work transitions in Sweden, Denmark and Finland', European Educational Research Journal, 18(3), pp. 278-297. doi: 10.1177/1474904119830037

Juvonen, T. (2015) Sosiaalisesti kontrolloitu, hauraasti autonominen. Nuorten toimijuuden rakentuminen etsivässä työssä. Nuorisotutkimusseuran julkaisuja, 165. Helsinki: Nuorisotutkimusseura.

Kallio, K.P. (2019) 'Elettyä kansalaisuutta jäljittämässä: Kansalaisuuden ulottuvuudet Nuorisobarometrissa', in Pekkarinen, E. and Myllyniemi, S. (eds) Vaikutusvaltaa Euroopan laidalla. Nuorisobarometri 2018. Helsinki: Finnish Youth Research Network/Youth Research Society, pp. 167-182. Available at: https://tietoanuorista. fi/wp-content/uploads/2019/03/NB_2018_web.pdf (Accessed: December 10 2020).

Kotipolku (2020) Available at: https://www.punainenristi.fi/kotipolku (Accessed: March 17 2020).

Kulmala, M. and Fomina, A. (this volume) Planning for the future: Future orientation, agency and self-efficacy of young adults leaving care in the Russian Arctic', in Stammler, F. and Toivanen, R. (eds) Young people, wellbeing and placemaking in the Arctic. London: Routledge, pp. 196-221.

Lawler, A. (2010) 'Collapse? What collapse? Societal change revisited', Science, 330(6006), pp. 907-909. doi: 10.1126/science.330.6006.907

Lewis-Beck, M. S., Bryman, A., and Futing Liao, T. (2004) The SAGE encyclopedia of social science research methods (Vols. 1-0). Thousand Oaks, CA: Sage Publications, Inc. doi: 10.4135/9781412950589 (Accessed: December 20 2020).

MacDonald, R. and Shildrick, T. (2007) 'Street corner society: Leisure careers, youth (sub)culture and social exclusion', Leisure Studies, 26(3), pp. 339-355. doi: 10.1080/02614360600834826. 
MacDonald, R. and Shildrick, T. (2013) 'Youth and wellbeing: experiencing bereavement and ill health in marginalised young people's transitions', Sociology of Health and Illness, 35 (1), pp. 147-161. doi: 10.1111/j.1467-9566.2012.01488.x.

MacDonald, R. and Shildrick, T. (2018) 'Biography, history and place: Understanding youth transitions in Teesside', in Irwin, S. and Nilsen, A. (eds) Transitions to adulthood through recession: Youth and inequality in a European comparative perspective. London, UK: Routledge, pp. 74-96.

Maiche, K. (2017) 'Nuoret turvapaikanhakijat ja luottamuksen rakentuminen arjen käytännöissä', in Honkasalo, V., Maiche, K., Onodera, H., Peltola, M. and Suurpää, L. (eds) Nuorten turvapaikanhakijoiden elämää vastaanottovaiheessa. Helsinki: Unigrafia, pp. 19-24.

Mertanen, K. (2020) Not a single one left behind: Governing the 'youth problem' in youth policies and youth policy implementations. Helsinki: University of Helsinki. Available at: https://helda.helsinki.fi/handle/10138/320548 (Accessed: December 15 2020).

Miles, S. (2000) Youth lifestyles in a changing world. McGraw-Hill Education. Buckingham: Open University Press.

Montgomery, H. (2007) 'Moving', in Kehily, M. J. (ed.) Understanding youth: Perspectives, identities and practices. London: Sage, pp. 283-312.

Munford, R. and Sanders, J. (2016) 'Understanding service engagement: Young people's experience of service use', Journal of Social Work, 16(3), pp. 283-302. doi: $10.1177 / 1468017315569676$.

Myllyniemi, S. (2017) 'Johdanto \& Tilasto-osio', in Myllyniemi, S. (ed.) Katse tulevaisuudessa. [Looking to the future]. Nuorisobarometri 2016. Nuorisotutkimusseuran/Nuorisotutkimusverkoston julkaisuja 189. Helsinki: Nuorisotutkimusseura, Nuorisoasiain neuvottelukunta, julkaisuja 56 and Opetus- ja kulttuuriministeriö, pp. 5-10.

Myllyniemi, S. and Kiilakoski, T. (2018) 'Tilasto-osio', in Pekkarinen, E. and Myllyniemi, S. (eds) Opin polut ja pientareet. Nuorisobarometri 2017. Nuorisotutkimusseuran julkaisuja 200. Helsinki: Nuorisotutkimusseura, Nuorisotutkimusverkosto, Valtion nuorisoneuvosto, julkaisuja 58 and Opetus- ja kulttuuriministeriö, pp. 11-117.

Myllyniemi, S. and Suurpää, L. (2009) 'Nuoret aikuiset itsellisyyden ja riippuvuuden noidankehässä’, Hyvinvointikatsaus 1/2009. Helsinki: Tilastokeskus, pp. 11-14.

Närhi, K., Kokkonen, T. and Mathies, A.-L. (2013) 'Nuorten aikuisten miesten osallisuuden ja toimijuuden reunaehtoja sosiaali- ja työvoimapalveluissa', in Laitinen, M. and Niskala, A. (eds) Asiakkaat toimijoina sosiaalityössä. Tampere: Vastapaino. pp. 113-145.

Paulsen, V., Höjer, I. and Melke, A. (2018) 'Editorial 'leaving care in the Nordic countries", Nordic Social Work Research, 8(1), pp. 1-7. doi: 10.1080/2156857X. 2018.1520805.

Pekkarinen, E. V. K. and Myllyniemi, S. (2012) Nuorten elinolot vuosikirja 2012. Lapset ja nuoret instituutioiden kehyksissä. Helsinki: Nuorisotutkimusverkosto and Terveyden ja hyvinvoinnin laitos.

Perälä, M-L, Halme, N. and Nykänen, S. (2012) Lasten, nuorten ja perheiden palveluja yhteensovittava johtaminen. Helsinki: Terveyden ja hyvinvoinnin laitos. Available at: http://urn.fi/URN:ISBN:978-952-245-529-1 (Accessed: April 20 2020).

Piitulainen, M. (2016) 'Kansainvälisen suojelun periaatteista ei voi alaikäisten kohdalla tinkiä', in Honkasalo, V., Maiche, K., Onodera, H., Peltola, M. and Suurpää, L. (eds) Nuorten turvapaikanhakijoiden elämää vastaanottovaiheessa. 
Nuorisotutkimusseuran and Nuorisotutkimusverkoston julkaisuja 120, pp. 14-18. Available at: http://www.nuorisotutkimusseura.fi/images/julkaisuja/nuorten_turvapaikanhakijoiden_elamaa_vastaanottovaiheessa.pdf (Accessed: September 20 2020).

Pirkkalainen, P., Mohamed, A. and Aaltio, I. (2018) Third sector hybridization and migrant integration: Cases of two migrant youth organizations in Finland. Electronic Journal of Business Ethics and Organization Studies, 23(2). Available at: http://ejbo.jyu.fi/pdf/ejbo_vol23_no2_pages_24-33.pdf (Accessed: January 18 2021).

Puuronen, A. (2014a) 'Millä saa pääsylipun yhteiskuntaan?', in Gretschel, A., Paakkunainen, K., Souto, A.M. and Suurpää, L. (eds) Nuorten yhteiskuntatakuusta nuorisotakuuseen. Nuorisotakuun arki ja politiikka. Nuorisotutkimusseura/ Nuorisotutkimusverkosto, julkaisuja 150, verkkojulkaisuja 76. Helsinki: Unigrafia, pp. 28-32.

Puuronen, A. (2014b) Etsivän katse. Etsivä nuorisotyö ammattina ja ammattialan kehittäminen-näkökulmia käytännön työstä [On the lookout. Outreach youth work as a profession and development of the professional field - aspects of practical work]. Helsinki: Nuorisotutkimusverkosto/Nuorisotutkimusseura. Available at: http://www.nuorisotutkimusseura.fi/images/julkaisuja/etsivan_katse.pdf (Accessed: April 20 2020).

Saari, J. (2019) Hyvinvointivaltio eriarvoistuneessa yhteiskunnassa. Toimi-hankkeen selvityshenkilönraportti30.1.2019. Availableat:https://vnk.fi/documents/10616/5698452/ Selvityshenkil\%C3\%B6+Juho+Saaren+raportti+30.1.2019+-+Hyvinvointivaltio+e riarvoistuneessa+yhteiskunnassa (Accessed: March 14 2020).

Skeggs, B. (2014) Elävä luokka [Self, Class, Culture]. Tampere: Vastapaino.

Sosiaali- ja terveysministeriö, (2020) Lastensuojelulain muutokset 1.1.2020. Available at: https://stm.fi/lastensuojelulain-muutokset (Accessed: March 14 2020).

Suomen Punainen Risti (2017) Aikalisä riitoihin, yösija tarvitsevalle - Nuorten turvatalo perustettiin 1990. Available at: https://www.punainenristi.fi/uutiset/20170511/ aikalisa-riitoihin-yosija-tarvitsevalle-nuorten-turvatalo-perustettiin-1990 (Accessed: March 14 2020).

Suurpää, L. (2009) Nuoria koskeva syrjäytymistieto: avauksia tietämisen politiikkaan. Helsinki: Nuorisotutkimusseura ja Nuorisotutkimusverkosto. Available at: http:// www.nuorisotutkimusseura.fi/images/julkaisuja/syrjaytymistieto.pdf (Accessed: January 31 2019).

Thomson, R. (2007) 'A biographical perspective', in Kehily, M.J. (ed.) Understanding youth: Perspectives, identities and practices. London: Sage, pp. 73-106.

Thomson, R., Bell, R., Holland, J., Henderson, S., McGrellis, S. and Sharpe, S. (2002) 'Critical moments: Choice, chance and opportunity in young people's narratives of transition', Sociology, 36(2), pp. 335-354.

Thomson, R. and Holland, J. (2015) 'Critical moments? The importance of timing in young people's narratives of transition', in Wyn, J. and Cahill, H. (eds) Handbook of children and youth studies. Singapore: Springer, pp. 723-733. doi: 10.1007/978-981-4451-15-4_35.

Thomson, R., Holland, J., McGrellis, S., Bell, R., Henderson, S. and Sharpe, S. (2004) 'Inventing adulthoods: A biographical approach to understanding youth citizenship', The Sociological Review, 52(2), pp. 218-239. doi: 10.1111/j.1467-954X. 2004.00466.x.

Wilson, S., Cunningham-Burley, S., Bancroft, A., Backett-Milburn, K., and Masters, H. (2007) 'Young people, biographical narratives and the life grid: young people's 
accounts of parental substance use', Qualitative Research, 7(1), pp. 135-151 doi: $10.1177 / 1468794107071427$.

Woodman, D. and Leccardi, C. (2015) 'Time and space in youth studies', in Wyn J., Cahill H. (eds.) Handbook of children and youth studies. Singapore: Springer, pp: 705-721. doi: 10.1007/978-981-4451-15-4_34.

Woodman, D. and Wyn, J. (2015) 'Class, gender and generation matter: Using the concept of social generation to study inequality and social change', Journal of Youth Studies 18(10), pp. 1402-1410. doi: 10.1080/13676261.2015.1048206. 